\title{
China and the first impact of the Industrial Revolution: initial conditions and a falling- behind trajectory until 1949
}

China e o impacto inicial da Revolução Industrial: condições iniciais e trajetória posterior de baixo crescimento até 1949

\author{
Hugo Eduardo da Gama Cerqueira (1) \\ Eduardo da Motta e Albuquerque (1) \\ (1) Universidade Federal de Minas Gerais
}

\begin{abstract}
This paper discusses the specificity of the initial impact of the British Industrial Revolution on China's economy. This approach is important to a better understanding of the nature of the beginnings of capitalism in that country, a process which was both intentionally and unintentionally influenced by the contacts between UK and China. These early conditions contributed towards defining the subsequent course of the Chinese economy, leading to a low-growth trap experienced between about 1870 and 1950 .
\end{abstract}

\section{Keywords}

China, Industrial Revolution, nature of Chinese economy, low-growth trap.

JEL Codes O30.

\section{Resumo}

Este artigo discute a especificidade do impacto inicial da Revolução Industrial britânica sobre a China. Essa especificidade é importante para entender a natureza do desenvolvimento capitalista inicial naquela região, moldado por processos não-intencionais e intencionais desencadeados pelos contatos entre o Reino Unido e a China. Essas condições iniciais contribuem para uma trajetória seguida posteriormente pela economia chinesa. Nesse sentido, este artigo investiga as origens de uma armadilha especifica enfrentada pela China - uma trajetória de baixo crescimento entre a segunda metade do século XIX e 1950.

\section{Palavras-chave}

China, Revolução Industrial, natureza da economia chinesa, armadilha do crescimento baixo.

Códigos JEL $O 30$. 


\section{Introduction}

The diffusion of the Industrial Revolution across the world was uneven. Different social formations received its impact in different ways, depending on their level of development, their knowledge of the changes brought by the new technologies, and the political and institutional arrangements for learning and absorbing those new technologies.

This paper discusses some aspects of the initial impact of the British Industrial Revolution on China, one of the wealthiest nations of that time as stated by Adam Smith (1976, p. 367) and identified by data provided by Maddison (2010) (see Figure 1, below).

According to Figure 1, China's estimated GDP was the largest globally, at least in 1500,1600,1820, and 1870. In the year 1000, India had the largest estimated GDP and in 1890 the United States had overtaken China. It is important to highlight that the UK during its hegemony never overtook China's estimated GDP.

Figure 1 GDP - China, India, UK and USA - Selected years between 1 AD and 1890 AD

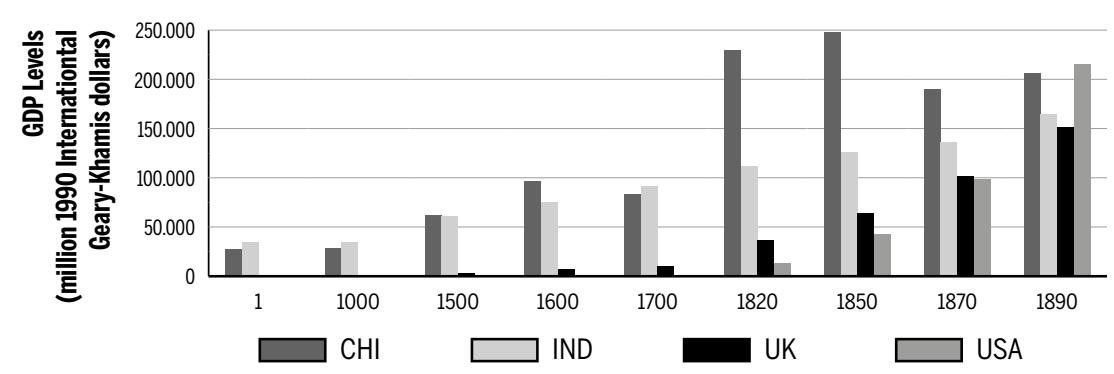

Source: Maddison (2010), author's elaboration.

China was also the largest manufacturing country in 1750, 1800 and 1830. The British Industrial Revolution changed this and in 1860 the UK had a larger share of global manufacturing than China (Allen, 2017, p. 323).

Since initial conditions matter, this first impact of the Industrial Revolution - or the first clash with the West (Spence, 1990, pp. 155) - had deep long term consequences, that may have contributed to the falling-behind period that predominated in the Chinese economy between the early $\mathrm{XIX}^{\text {th }}$ Century and the first half of the XX $\mathrm{XX}^{\text {th }}$ Century (for the period between 1870 and 1949, see Figure 1 in the Introduction of this Special Issue). 
The Industrial Revolution had an uneven impact throughout the world, and the first clashes between traditional societies and the new capitalist dynamics were very important to define subsequent dynamics. In this sense, initial conditions matter: the outcome of this first clash will define how the traditional economy - pre-capitalist economy - will react to the initial contact with this new dynamic force - "the expansionary force of the first industrial nucleus" (Furtado, 1987, p. 217). In the case of China, the outcome was a falling-behind period.

The unevenness of the initial impact of the Industrial Revolution is the result of various features, among them the political situation of each society: was the political arrangement of each society stable, ascending or declining? China was the wealthiest nation in the world in 1800, but her political system was in crisis and these political factors matter. In the case of China, the environment of decline and crisis is important, at least since the White Lotus Rebellion (1796-1804): for Jones and Kuhn (1978, p. 143144), "it was the White Lotus Rebellion, rather than the Opium Wars, that demonstrated the irreversible decline of Ching military power".

Jones and Kuhn (1978, p. 144) stress the "acute awareness of the need for reform" during the 1820s and 1830s. Between 1840 and 1865 China faced two Opium Wars and the Taiping Rebellion, events that were both signs of decline and sources of further problems. Data estimated by Maddison (Figure 1) show the impact of those political and military problems upon China's wealth, as the GDP estimated for 1870 is less than the estimated for 1850 .

Those long-lasting and multiple internal crises certainly weakened the nation's capacity to react to the Industrial Revolution - represented by the initial military presence of British Navy and the efforts to open the Chinese market to industrial products - the opening of Chinese markets was a key event mentioned by Polanyi (2001, p. 6). In what today is India, the British did not meet an organized state as in China, but a region with "its multiple fragmentations - ethnic, linguistic, dynastic, social, confessional" (Anderson, 2012). The most important and the largest political unit of that configuration, the Mughal Empire, was under a political stalemate and living an internal crisis when the British arrived there in the XVIII ${ }^{\text {th }}$ Century (Metcalf and Metcalf, 2001, pp. 51-52).

Spence (1995, pp. 155-274) describes the period after China's "first clash with the West" as one of "fragmentation and reform". There was "cri- 
sis within" that fragmented China, from the internal rebellions in the late XVIII ${ }^{\text {th }}$ Century, to the military defeats in the two Opium Wars (18401842 and 1858-1863), the Taiping Rebellion (1850-1864), the Nian Rebellion (1851-1868), and the Muslim Revolts (1855-1873).

It is important to stress this dynamics of fragmentation after the "first clash with the West". Political stalemate, political inertia and fragmentation are phenomena that undermine China's capacity to prepare a response to the challenge coming from the West. Political inertia and fragmentation is a political situation that could be identified also in the XVIII ${ }^{\text {th }}$ century Mughal Empire in India (Metcalf and Metcalf, 2001) and in post-independence Latin America (Escosura, 2006). This situation is in strong contrast with the process in the former British colonies, independent since 1776 and in a process of unification, territorial expansion and with policies to face the British challenge - Hamilton's (1810) Report on the subject of manufactures is an expression of a political decision to build a response to a new challenge.

The situation of XIX ${ }^{\text {th }}$ century Ching Empire in China can be contrasted also with Japan. The connections between the Chinese and Japanese clashes with Western technologies can be seen in the way Japan learned with China: according to Jansen (1980, p. 341-342) "the most important result of the Japanese perception of Chinese disasters was the resolve not to repeat the Chinese experience". Japan, that in 1853 received the visit of Commodore Perry, is a country that had time to change with the Meiji Restoration in 1868 - the context of the American Civil War in the early 1860s probably contributed to this. In 1868 a new political arrangement in Japan renewed its political leadership, a top-down political change, creating a leadership able to coordinate later reforms - a state that led the industrialization process, facing the challenge created by the Industrial Revolution with a clear set of public and industrial policies (Skocpol, 1984; Okhawa and Kohama, 1989).

In sum: China faced the first impact of the Industrial Revolution with an empire in crisis. Inertia, lack of previous knowledge of Western technologies and delayed response to them were the conditions created by its political arrangement. Two events that took place after the arrival of the British contributed to this process: the Opium Wars (Wakeman, 1978) and the Taiping Rebellion (Kuhn, 1978). Both are part of the explanation why the initial contact was shaped in the peculiar way presented by the literature reviewed in this paper. 
The objective of this paper is to understand the specificity of China's initial reception and processing of the British Industrial Revolution and consequent changes. This specificity may be important to understand the nature of the initial capitalist development in that region, shaped by unintentional and intentional processes triggered by the contacts between UK and China. And this starting point is important to investigate the path opened by that very peculiar beginning. In this sense, this paper investigates the origins of a low growth trajectory that characterized China between 1870 and 1950 - a specific trap faced by China.

This paper is organized in five sections. The first presents China's position in the early XIX ${ }^{\text {th }}$ century. The second connects the Industrial Revolution and British global expansion. The third summarizes how the defeats in the Opium Wars forced a new perception on the position of China in a new global order. The fourth section presents initial consequences, unintentional and intentional, triggered by those military defeats. The fifth section concludes this paper connecting the "first clash" with British Industrial Revolution and the Chinese trajectory in a low growth trap until 1949.

\section{China's economy, her global position in the late $\mathrm{xviii}^{\text {th }}$ century and her perceptions of that position}

It is not easy to discuss a complex and long-lasting society such as China. The achievements of ancient China are impressive and during centuries she was a leading global center for technology. Needham (1954, p. 242) shows important new products and technologies such as paper, pig iron, powder, magnetic compass that diffused from China to the West - with lags of 100 to 1000 years. This direction of technological flow persisted, according to Mokyr (1990), at least until 1200, when "the economy of Western Europe had absorbed most of what Islam and the Orient had to offer" (p. 40). This process was perhaps concluded by 1500, when "Europe had more or less achieved technological parity with the most advanced parts of the Islamic and Oriental worlds" (1990, p. 55).

Even after that, Pomeranz (2000, p. 45) evaluates that in the late eighteenth century "[i]n many areas of textile weaving and dyeing, western Europeans were still working on imitating Indian and Chinese processes; the same was true of manufacturing porcelain." 
Those historical bases provided ground for China's position in the global context: according to Figure 1, in 1800 China had the largest GDP in the world (Maddison, 2010), and, according to Allen (2017, p. 323), it was the largest manufacturing country.

Writing on the eve of the first Industrial Revolution, Adam Smith reserved a prominent place for China in his reflections on The Wealth of $\mathrm{Na}$ tions. The country is mentioned a few times in the book, on more or less isolated pages, but Smith's interpretation of its situation and development differs from those presented by other authors of the same period. He is more concerned with understanding the specificity of the Chinese case, contrasting it with that of European countries, than with condemning or celebrating that model in the light of some idealized conception of economic development (Hanley, 2014, p. 373, 381).

According to Smith, the improvements in Chinese agriculture and manufacture probably go back to a remote past. In the Eastern provinces, the existence of a vast network of navigable rivers provided canals "more extensive than that either of the Nile or the Ganges, or perhaps than both of them put together" through which trade could expand and so, by means of an increased division of labor, the production of wealth could be enlarged (Smith, 1976, p. 35). Besides that, "the great extent of the empire of China, the vast multitude of its inhabitants, the variety of climate, and consequently of productions in its different provinces, and the easy communication by means of water carriage between the greater part of them, render the home market of that country of so great extent, as to be alone sufficient to support very great manufactures, and to admit of very considerable subdivisions of labor" (p. 680-1).

In addition to these natural advantages, Smith drew attention to the care with which the sovereign of China made and maintained "good roads and navigable canals, in order to increase, as much as possible, both the quantity and value of every part of the produce of the land, by procuring to every part of it the most extensive market which their own dominions could afford" (p. 838). Smith explained that the sovereign's attention with the maintenance of roads and canals was not the result of a careful consideration of the interests of his subjects, but rather the consequence of his interest in increasing his own revenue, which rested on the volume of agricultural production: "the revenue of the sovereign arises almost altogether from a land-tax or land-rent, which rises or falls with the rise and fall of the annual produce of the land" (p. 730). 
In short, Smith considered China much richer than any other part of Europe (p. 208, 255). This opulence was the consequence of its national geography and of the fact that the government took care of "erection and maintenance of the public works which facilitate the commerce of any country, such as good roads, bridges, navigable canals..." (p. 724). But despite being "one of the richest, that is, one of the most fertile, best cultivated, most industrious, and most populous countries in the world" (p. 89), it seemed to Smith that China had remained stationary for a long period, "and had probably long ago acquired that full complement of riches which is consistent with the nature of its laws and institutions" (p. 111). ${ }^{1}$ This situation contrasted with the fast growth in North America and the slow growth in Europe (p. 98) and explained the miserable condition of the lower ranks of the Chinese society, whose poverty "far surpasses that of the most beggarly nations in Europe (...) The accounts of all travellers, inconsistent in many other respects, agree in the low wages of labor, and in the difficulty which a laborer finds in bringing up a family in China. If by digging the ground a whole day he can get what will purchase a small quantity of rice in the evening, he is contented. The condition of artificers is, if possible, still worse. Instead of waiting indolently in their work-houses, for the calls of their customers, as in Europe, they are continually running about the streets with the tools of their respective trades, offering their service, and as it were begging employment." (p. 89).

The reason for this condition must be found in the pressure caused by the natural growth of the population and the constant demand for labor in a stationary economy, forcing the workers to compete for a job. In addition to emphasizing the challenges faced by the Chinese workers and the devastating moral consequences of their miserable condition, Smith pointed out what needed to be done to change this situation. Although China "acquired that full complement of riches which the nature of its laws and institutions permits it to acquire" (p. 89) it should be considered that "this complement may be much inferior to what, with other laws and institutions, the nature of its soil, climate, and situation might admit of" (p. 111). According to Smith, a change in the Chinese laws and institutions

1 Although Smith's sources are not clear - and one should never forget his complaints and distrust of the statistics available in his day (Redman, 1997: 250-253) -, Smith's opinion is compatible with modern estimates of the evolution of the Chinese GDP per capita over the eighteenth century: according to Maddison (2010) it would have remained stable between 1700 and 1820. 
could allow economic growth to resume, with a consequent increase in wages and living conditions of the workers and his families. "The Chinese", Smith wrote, "have little respect for foreign trade" (p. 680). Instead of persisting with policies that intended to favor or to promote agriculture at the expense of other economic sectors, China should abandon its prejudice against foreign trade. Trade liberalization could add the foreign market to China's home market. It would revert the negative effects of the trade restrictions on agricultural production, ${ }^{3}$ improving tax revenues at the same time as the well-being of the population. It also would hardly fail to stimulate the production of manufactures of China, improving the division of labor and the productivity of the manufacturing industry. Further, "by a more extensive navigation, the Chinese would naturally learn the art of using and constructing themselves all the different machines made use of in other countries, as well as the other improvements of art and industry which are practiced in all the different parts of the world" (p. 681).

Notwithstanding Smith's opinions on the prospects and policy options facing China, it would take too long for them to have any influence on the Chinese development debates. The first mentions to the Wealth of Nations in China were made in 1880's (Shaowen, 2002). In 1895 - the year of China's humiliating defeat by Japan -, Yan Fu (1853-1921), a reformist thinker and an important promoter of the ideas of British philosophers and social scientists, expressed his intention to translate Smith's book into Chinese in order to reveal to his countrymen the secrets of Western power and prosperity, a development that he attributed to the influence of Smith's ideas. Whether right or wrong, Yan Fu and his contemporaries believed that the knowledge of economics - particularly of Smith's book -was of direct im-

2 For Smith, when accumulation exceeds the pace of population growth, the scarcity of hands and competition among employers causes wage growth: "it is not the actual greatness of national wealth, but its continual increase, which occasions a rise in the wages of labour. It is not, accordingly, in the richest countries, but in the most thriving, or in those which are growing rich the fastest, that the wages of labour are highest" (Smith, 1976, p. 86). In a stationary economy "the hands, on the contrary, would (...) naturally multiply beyond their employment (...) and the labourers would be obliged to bid against one another in order to get it." In this way, wages would soon be reduced to the "lowest rate which is consistent with common humanity" (p.89). Therefore, the solution to the Chinese problem depended on an institutional change that would enable growth to resume, which in turn would promote wage growth.

3 Such as the reduction of the real value of the surplus produce of land and the withdrawal of capital from agriculture induced by the decline of the relative profitability of agriculture vis-à-vis other sectors (p. 672). 
portance for the development of China (Borokh, 2012: 414). It took him six years to complete the translation, which was published in 1901-2, "in eight volumes, printed lithographically and bound in the traditional Chinese style" (Shaowen, 2002, p. 212). Fu's translation was praised, but it had a limited circulation, restricted to the literati and government officials. This was due, among other reasons, to his decision to translate the book into the classical Chinese, instead of using the vernacular.

It is not simple to define the nature of the Chinese economic system by 1800 . This is the subject of an important theoretical debate that is far beyond the scope of this paper. At least three different approaches and positions should be mentioned in order to organize the discussion: a tributary mode of production (Banaji, 2010), a combination of a market economy with "command and customary economies" (Myers and Wang, 2002), or a "redistributive economy" (Polanyi, 2001). Those evaluations can be combined and a dialogue between them could be organized. What is important is to stress the non-capitalist nature of eighteenth century Chinese economy, an economy that was to receive the impact of the British Industrial Revolution.

Describing the Chinese economy in the early XIX ${ }^{\text {th }}$ century, Myers and Wang (2002, p. 577) comment the "vitality of Ching market, command and customary economies". ${ }^{4}$ Handicraft industries were strong, basically underpinning the global position of Chinese manufacturing, with important activities such as text weaving and dyeing. "Cotton cloth products constituted the second most important commodity (after food grains) to circulate in the Ching market economy" (Myers and Wang, p. 619). According to Myers and Wang, there were four market relationships, with brokers organizing transactions between: a) farmers and spinners and weavers; b) spinners and weavers selling their yarn or cloths; c) handicraft producers purchasing cloth and selling their products to brokers; d) cloths may be further processed by dyeing and calendaring and again sold to brokers or merchants (pp. 619-620). Those interactions through market are related to the "small-scale economic organizations", "cell-like or reticular economic organization" (Myers and Wang, p, 586).

4 According to Myers and Wang (2002, p. 563), "in the customary economy, households participated in production and exchange according to convention and institutions (rules, practices, beliefs and so forth)". Myers and Wang use John Hicks' (1969) concepts that identify two pure forms of non-market economy: customary and command economy (Hicks, 1969, p. 14). 
Other important handicrafts were sugarcane and sugar processing, sericulture and silk processing - the "scale of this silk handicraft industry was enormous" (p. 623) -, and tea. Salt was the subject of "hybrid economic organizations", as there was a Ching state monopoly of this good, the "third most important marketed commodity" (p. 624). The market economy, in 1800, involved 20,000 market towns (p. 582). Those market towns are part of the "Chinese marketing system" described by Skinner (1964, 1965).

The "imperial state made revitalizing agriculture its highest priority" (Myers and Wang, p. 578). The interactions between the "imperial state" and the market economy were important, as "the imperial policies modulating the market economy enabled rice prices to continue their smooth, slow growth during the eighteenth century".

An economic articulation that answered to the new issues and demands between 1644 and 1800: "whether in agriculture, handicrafts, or services, Chinese accommodated for scarcities of any vital inputs by using more labor, the final feature of the Chinese economy's expansion during our period" (p. 590). This flexibility included a capability to respond to foreign demand.

China's economy and her position in foreign trade had implications for the balance of payments between China and the West: during the XVIII ${ }^{\text {th }}$ century a huge demand in Europe and America for tea, porcelains, silk, decorative goods (Spence, 1995, p. 140). Myers and Wang (2002, p. 587) articulate the "proliferation of market towns" during the XVIII ${ }^{\text {th }}$ century "to the expansion of foreign trade, in which the exports of port cities like Macao and Canton - silk products, ceramics, sugar, sandals, and so on were exchanged for products from Southeast Asia.... Trade between Canton and Europe grew at a rate of 4 percent a year between 1719 and $1806 \ldots$ Such foreign trade helped connect China's interior markets to its costal city ports, providing additional demand for domestic producers" (p. 587). This comment of Myers and Wang put forward the strategic importance of Chinese city-ports to the overall economic dynamic, since the XVIII ${ }^{\text {th }}$ century. This integration (limited, but real) between city-ports and the Chinese rural marketing system (Skinner, 1965) is important to stress it has a dynamic, it is long lasting, and it shows how a change in one point, a city-port, might have consequences for the whole market network.

What was the Chinese economy like at the beginning of the XIX ${ }^{\text {th }}$ century? According to Myers and Wang (2002, p. 645): "What made the huge market economy unique was its ability, without capitalism, to mesh 
tightly with the liturgical organizations to the command economy to support a huge agrarian-bound workforce and population that constituted the customary economy and that integrated with a nonagrarian urban sector of minuscule proportion. This triadic economic system favored labor-intensive and land-saving methods for implementing modest technological change". The handicraft sector of that economy responded for more than 20 percent of global manufacturing in 1800 (Allen, 2017, p. 323).

Therefore, in the first half of the XIX ${ }^{\text {th }}$ century the Chinese economy and its position in the global context were part of a framework in which the British economy had deficits. The triangular trade between India, China and Britain was unfavorable to the British: "the English could find nothing manufactured in Europe which the Chinese would consume in quantities proportional to the gigantic English demand for tea" (Wakeman, 1978, p. 168).

The diagnostics of an economic stagnation was already presented by Adam Smith, and it is important to remember that his opinion on China's stationary state was a conviction shared by his contemporaries (Hanley, 2014; Chen, 2004). It should also be noted that Smith's assessment of China's stagnation was formulated before the dramatic changes created by the Industrial Revolution, a development that would add new elements to the inertial condition of the Chinese economy.

Later, John Barrow (1764-1848), sent to China in 1792, stated that "from the middle to the end of the sixteenth century, compared with Europe in general, it [i.e., China] had greatly the superiority, if not in science, at least in arts and manufactures, in the conveniences and the luxuries of life. The Chinese were, at that period, pretty much in the same state in which they still are; and in which they are likely to continue." (Barrow, 1804, p. 29; this passage is also quoted in Chen, 2004).

Looking from the vantage point of the present, Feuerwerker (1980, p. 68) is better positioned than Smith and his contemporaries to diagnose the situation: "[t]he plain facts are that by mid-nineteenth century, if not earlier, China's economy had reached the limits of development possible with the technology (mechanical and organizational) at its disposal....". This evaluation is in line with Elvin (1973, p. 312-313) that identifies a "high level equilibrium trap" in Chinese agriculture, since "agricultural productivity had reached the limits of what was possible without the industrial-scientific inputs" (p. 312). 
Although large and sophisticated, with the triadic economic system pointed out by Myers and Wang (2002), this economy that had reached the limits of its dynamism would suffer an external shock coming from a vibrant and expansionary new economic system - it would be transformed by new dynamic forces triggered by industrial capitalism.

The size, wealth and past achievements of Chinese society help us understand China's self-perception of her global position in early nineteenth century. In 1793, the emperor, Qianlong, sent a message to George III: "there is nothing we can lack" (Hao and Wang, p. 143). Chinese elite thought that this message was enough to keep away that distant and barbarian nation from the Chinese coast. Hao and Wang mention "sinocentrism" and "Chinese superiority" (p. 143), and "overconfidence" of Chinese elites (p. 155).

However, the lack of new British pressures on China was not a consequence of this missive to George III, but rather of the Napoleonic Wars. And China was not aware of this important geopolitical event (Spence, 1995, p. 159). The solution of those wars created a new geopolitical scenario - the "one hundred years of peace", according to Polanyi (2001, chapter 1). Darwin $(2007,185)$ discusses the consequences of this new geopolitical context in Asia, showing how the British position at the end of the Napoleonic Wars enabled it to further expand in Asia - "Bengal... the lever they needed to force open door into South China economy" (p. 186).

Beyond overconfidence, at this moment of Britain's expansion towards South China, China's coastal regions were not seen as the major problem for the Ching state. Strategically, in the early XIX ${ }^{\text {th }}$ century the main focus of attention of the Chinese empire was the "Inner Asian frontier" (Hao and Wang, 1980, p. 146). Only after 1840 between the literati was there interest "in world geography" and "towards obtaining knowledge of the unknown Western world" (Hao and Wang, 1980, p. 147).

\section{The "expansionary force" of Industrial Revolution}

The economic processes triggered by the Industrial Revolution underlie the "domestic sources of British expansion" (Darwin, 2009, p. 36). Darwin points out the role of British merchants' houses in this expansion (p. 36), with a "fourfold increase between 1834 and 1860 in the tonnage 
of shipping that used British ports" (p. 37). One "notable feature of this commercial expansion.... was the shift towards markets in Asia and the Near East... and in Africa and Australasia" (p. 37). Among those sources of expansion, Darwin indicates "[a]bove all, by the 1830s, with the arrival of power-weaving, the British could undercut competition across the whole range of cotton manufactures (the most widely traded commodity), and break in new markets with products as much as two hundred times cheaper than the local supply" (2009, p. 37).

Those new technologies transformed the international division of labor, establishing what Darwin (2007) identifies as an "astonishing reversal" (p. 196): in the eighteenth century India was the "textile workshop of the world" (Darwin, 2007, p. 193) and after the Industrial Revolution UK replaced India. This transformation affected China also, as until 1830 "England purchased more nankeens ... each year than she sold British-manufactured cloth to China" (Feuerwerker, 1980, p. 18). Those changes took place in the first half of the XIX ${ }^{\text {th }}$ century, as Allen $(2017$, p. 323) shows that in 1860 the UK had become the largest manufacturing nation in the world.

This "expansionary force of the first industrial nucleus" (Furtado, 1987, p. 217) creates a new international division of labor (Furtado, 1987, pp. 216-224). Every region of the world was pressed to change its role in this new international division - even nations that were suppliers of mineral and agricultural products had new demands to fulfill and introduced new products, with a consequent new composition of their foreign trade.

One global outcome of this process was Britain becoming "the octopus power" (Darwin, 2009, pp. 64-66). In this position of a leading nation of the "octopus power", British merchant houses were distributed globally (1,500 houses in late 1840, 1,000 abroad) (p. 37), and military troops were also distributed globally (see Darwin, 2009, p. 34, Map 1, for a worldwide distribution of British troops in 1848).

Economically, the first clash (Spencer, 1995) with British economy was a clash between two different economic systems in different moments of their histories: a stagnated economy in China facing a dynamic expansionary system in Britain. The bases of Chinese foreign policy were anachronistic, especially because they were suited to a pre-industrial age: "Once foreign merchants had come just for Chinese goods. Now, Western manufacturers were beginning to look for Chinese markets" (Wakeman, 1978, p. 174). Politically, the Chinese (imperial) state in crisis, without un- 
derstanding a new global scenario, faced the British state, an ascending force, living in and leading a new global order built upon the outcome of European wars, a state with military strength and a clear focus.

This "first clash" had military implications. In the global expansion of British position, according to Darwin (2009, p. 40), "China was much the most striking case where military power was used in the interest of trade".

\section{Opium wars: defeats and perception of a new situa- tion}

Wakeman (1978) and Fairbank (1978) describe the context, the wars and initial consequences of Chinese defeat.

The Opium Wars demonstrated the lack of preparation of the Chinese imperial state to deal with the new situation. According to Fairbank (1978, p. 213), the Chinese state had a priority "in the late 1830's": "simply to solve to stop an evil, the Anglo-Indo-Chinese opium trade". To face this problem, there was lack of lack of knowledge: the military defeat was a surprise, the technologies of British military caused a great impression in China. This military power depends upon technology and this relationship began to be an issue in China.

The outcome of those wars presented further evidence on the relationship between technology, military power and trade. The use of military power to obtain trade concessions is very clear in Article XII of the Treaty of Nanking: "...but the Islands of Koolangsoo and that of Chusan will continue to be held by Her Majesty's forces until the money payments, and the arrangements for opening the Ports to British Merchants be completed" (available at https://china.usc.edu/treaty-nanjing-nanking-1842).

The first Opium War opened the Chinese market for British merchants, triggering a process that begins the transformation of Chinese economy unintended effects. Unintended consequences because the development of capitalism in China was not among the objectives of British merchants.

The defeat in itself was an expression of economic stagnation and political stalemate - political inertia. But the defeat in the first war triggered further political crisis. The Taiping Rebellion has many roots, one of them is the defeat and the new conjuncture with foreign merchants in the treaty-ports. If the Chinese imperial state had difficulties to deal with 
the pre-defeat conjuncture, after that those difficulties only increased. As Fairbank writes (1978, p. 244), "[d]uring the civil war and turmoil of the 1850s within the major provinces, accordingly, the Western merchants, missionaries and military on the coast seemed quite peripheral - only a border problem". And, Fairbank insists, "Peking's acquiescence in the Anglo-French demands of 1858 must be seen in this context of domestic priorities" (p. 253). The Ching state after the treaties received support from Western powers to face the Taiping Rebellion, a way to preserve the terms of those treaties (Spence, 1995, p. 186).

The two defeats in two opium wars created and consolidated the treaty system. "In its economic aspects, the mixed Sino-foreign order was at first mainly confined to the foreign trade, where Chinese merchants joined with foreign counterparts" (Fairbank, p. 260). Further combined changes in transport and communication "brought the China trade more fully into the world market and subject to its vicissitudes" (p. 263).

Initially, even those military defeats did not trigger change, given the inertia in Ching Empire. Hao and Wang (1980, p. 154) mention that the emperor, even after the first opium war, regarded the Treaty of Nanking as "a device that would 'permanently prevent further problems from happening'" (p. 154). "Misunderstanding and intellectual-institutional inertia" were part of the situation, with important implications: "[r]efusing to take foreign realities into account, China did not develop a nationwide sense of urgency until more intense shocks stunned the Middle Kingdom" (pp. 155-156).

Perceptions of the great change began after 1860, when "a segment of the literati realized that China was facing a new situation the like of which she had not seen in a thousand years" (Hao and Wang, 1980, p. 156).

In the end, those changes in perception led to movements intended as "self-strengthening" in the late XIX ${ }^{\text {th }}$ century. It is important to stress how late those changes came. Those difficulties to perceive what was happening in the West, to understand that an Industrial Revolution was taking place, might suggest that China "did not know that they do not know". This is important because, in order to organize policies for development, a nation needs to understand its position in the global context and needs to define a benchmark to guide her policies. This lack of awareness differentiates the Chinese case from other European countries, USA and Meiji Japan. 
As Spence (1995, p. 201) mentions, only in 1873 was China again unified under the Ching - but there were the treaty ports. Important cities, hubs in networks of marketing areas in the hinterland, the treaty ports were "a special sector of the Chinese polity in which Chinese sovereignty was not extinguished, but was overlaid or supplanted by that of the treaty powers" (Fairbank, 1978, p. 260). A very peculiar dynamics took place under that arrangement.

\section{Initial changes triggered by those military defeats}

As Fairbank sums up, "[t]he treaty system had been set up by gunfire and had to be maintained by gunboat diplomacy" (1978, p. 232). Military superiority depends on technology. This was the result of the "first clash with the West". Economically, the consequence was the opening of the market in selected city-ports in China. China was not a colony, there was a vast hinterland outside direct control of foreign military or foreign economic forces.

But this market opening triggered processes, some unintended and others intended. Unintended perhaps were the processes derived of foreign commercial presence in the treaty ports - processes initiated as soon as the treaty became operational. Intended consequences could be those derived from the late response of the Ching state in relation to access to foreign technologies and industries, an organized - but belated and limited - effort to absorb more advanced technologies. Each of those processes changed Chinese economy, and their combined effects defined what would be the beginnings of Chinese capitalism - a trajectory of low growth that would persist until the fall of the Ching Empire in 1911 and the end of civil war in 1949.

\subsection{Unintended consequences: treaty-ports and capitalist "bridge- heads"}

In treaty ports British merchants and later merchants from other European countries, from the USA, and after 1895, from Japan, were able to organize commercial activities, especially imports of industrial goods. In 1842 they 
were 5 cities (Spence, 1995, p. 169), in 1860 they were 17 ports (Spence, pp. 189-190), by 1914 there were 92 cities "formally opened to foreign trade" (Feuerwerker, 1983, p. 33).

This initial and localized opening to British Merchants, in selected ports, had a series of consequences: "The two decades of 1840s and 1850s constituted a first phase of a new order in China's foreign relations... Later phases saw the treaty system grow into a more and more important element in Chinese state and society... In the succeeding generation from the 1860 s to the 1890 s the treaty ports became urban centers of a Sino-foreign condominium and hybrid culture, all of which had an increasing effect on China as a whole" (Fairbank, 1978, p. 214).

Those city ports had strong connections with inland China. There was a strong relationship between domestic and foreign commerce through the periodic markets of standard market towns: agriculture surplus and products of handicraft manufacturing were "exchanged by other local commodities or goods manufactured in the treaty ports or imported from abroad" (Feuerwerker, 1980. p. 40): According to Feuerwerker, 63,000 "basic markets" described by Skinner were connected to intermediate and central levels and those to the "great trading cities of the coast (Tientsin, Shanghai and Canton)" (1980, p. 40). Although it had a "high level of traditional development", this "nineteenth century commercial system" was not a "'modern' market economy" (p. 44).

The existing interconnections were enough to define that changes at one point - treaty ports - would reverberate to the rest of the economy. There were different channels for these effects. One channel was through the changes in the nature of imported goods. Feuerwerker (1980) describes how new imports of yarn from UK affected handicraft production in China: imported yarn strengthened the handicraft weaving industry (p. 19), there was growth of foreign imports of cotton yarn and cloth (p. 19) and there were geographical changes of textile production, as the "principal markets for imported machine-spun yarn were those regions where cotton growing and handicrafts were least developed" (p. 22). This "inflow of foreign yarn" led to a "geographical dispersion of the handicraft weaving industry", and in a very peculiar combination, "the adoption of machine-made yarn, moreover, strengthened handicraft weaving industry as a whole" (p. 22). This process exemplifies how a change in the coastal region affected important sectors of the hinterland (Feuerwerker, 1980). 
The opening of treaty-ports to foreign products had an uneven effect in the manufacturing sector. On the one hand, handicraft industries like native iron and steel "nearly disappeared by the end of the nineteenth century" (p. 26). On the other hand, there were sectors unaffected: oil pressing, rice milling, and mining by native methods, silk weaving (p. 27).

Those changes affected the nature of Chinese exports, as from 1887 "raw silk replaced tea" ... "as the most important single export" (p. 26).

Among the changes that took place in those treaty-ports, there was an initial segment of modern industry: located in those cities, prior to 1895 "approximately 103 foreign-owned industrial enterprises, most of them small firms" (p. 28).

In those treaty-ports the rise of international trade gave room to an initial accumulation of wealth among sectors of Chinese intermediaries and new social groups. Chang (1980. p. 274) summarizes those changes, "the socio-economic transformation that took place in the principal treaty ports": "[t]here, to begin with, Western expansion generated a sustained, cumulative economic growth which resulted in a more or less 'modern' sector of the economy in those cities closely bound up with the external world market. Related to this economic development was a process of social change which led to the emergence of such new groups as the comprador-businessmen, salaried professional workers and an urban proletariat." (Chang, 1980, p. 274-275).

Those changes were also one starting point for the "Chinese bourgeoisie", as Bergère (1983, p. 724, p. 727) suggests: "[t]he formation of the Chinese bourgeoisie sprang also from extraneous circumstances: foreign intervention and the growth of concessions in treaty ports" (p. 727). The wealth accumulated in those cities, according to Feuerwerker (1980, p. 57), was a source for that initial formation of industrial firms: "[m]any of the original investors in Chinese-owned shipping, financial and manufacturing enterprises were men who had grown wealthy as compradors of the leading foreign firms in Shanghai".

\subsection{Intended consequences: self-strengthening as a (late) political movement with industrial consequences}

After two military defeats and a deep crisis within the country, part of those 
internal crises fed by the new foreign presence in a growing number of treaty ports, a belated development of a conscience within China of the problems related to her position in the new global context, led to a broad movement called "self-strengthening" (Kuo and Lio, 1978; Teng and Fairbank, 1979).

According to Kuo and Lio (1978, p. 491), this movement may have begun by 1861 , by literati-officials sensitive to the fact that "a new policy was needed to meet the unprecedented change in China's position in the world" (p. 461). Teng and Fairbank (1979) organize this process in three different phases. The first, between 1839 and 1860, "recognition of China's need to know the West", the second, between 1861 and 1870, "the desire for Western technology", and the third, between 1871 and 1896, "the effort at self-strengthening".

As in other parts of the world, military considerations were important to change how Western technology should be viewed - "since European military power appeared to depend upon technology, the adoption of this technology was regarded as the primary task" (Kuo and Lio, 1978, p. 492).

A "considerable range of activities was proposed for this end" (Kuo and Lio, 1978). In the early phase of this process, Kuo and Lio (1978) describe long range plans, related to investments in "arsenals and shipyards" (pp. 519-525), "Western learning" (pp. 525-532), an "arsenal and shipyard schools" (pp. 532-537) and "training abroad" (pp. 537-542)

Although the military issue was an important driving force of this selfstrengthening movement, in the late 1870s it became "more diverse and complicated than it seemed in the 1860s". "The application of Western technology to transportation and industry within China had begun to shift the focus of the effort from defense to industrialization" (p. 542). Hao and Wang (1980, p. 171) mention that "non-military aspects of industrialization slowly gained popularity, and during the last quarter of the nineteenth century the reform-minded officials looked to the construction of industries for civilian needs", all employing Western technologies.

Although there were "half-way measures", there were "far-reaching results", according to Kuo and Liu: a "departure from traditional statecraft" (p. 491), "new Ching foreign policy" (p. 492) and an awareness of the relationship between technology and military power (p. 492).

Resulting from this process, initial investments with government initiative are presented by Feuerwerker (1980, p. 32) as the first Chinese-owned enterprises. Those firms were distributed between 19 government-owned 
arsenals and shipyards; arsenals with "machine shops for the production and repair of tools and parts; "secondly, a number of official and semiofficial mining, smelting and textile enterprises had been undertaken from as early as 1872". (p. 32). There were also 75 manufacturing firms other than arsenals (silk reeling, cotton ginning, cotton spinning, flour milling, matches, paper mills) and 33 coal and mining metal mines established between 1872 and 1894 (p. 33).

In a combination of unintentional and intentional changes, one product of the treaty ports, the compradors, accumulated resources for new investments. According to Bastide-Bruguiere (1983), "[c]ompradors not only had the financial capacity but also were willing to invest in new sectors. They were the first to make large sums of money available for the founding of modern enterprises and played a decisive role in their launching. It has been estimated that they provided 30 per cent of the capital for the six steam-navigation companies in Shanghai between 1862 and 1873; 62.7 per cent of the capital needed to open coal mines between 1863 and 1886; 23.23 per cent of the capital needed by twenty-seven large Chinese cotton mills opened between 1890 and 1910; and 30 per cent of the capital needed by Chinese machine manufacturing during the same period". (Bastide-Bruguiere, 1980, p. 551).

However, there were limits to the Ching empire ability to act as a developmental agent. (Feuerwerker, 1980, p. 59). The "Ching political system" was a political arrangement that was able to keep China united under the different stresses of foreign wars and internal rebellions, but. as mentioned above, it was a state with signs of exhaustion and incapacity to organize a response to new challenges. "The central government normally confined its economic role to claiming its share of a relatively fixed economic product and to providing the internal order and external defenses which would permit that product to be reproduced from one year to the next" (p. 60). As discussed in the previous sub-section, only after 1861 were there early signs of a conscience of a new international context. This Ching political system, therefore, was structurally and conjuncturally unable to implement catch up policies: "[n]either the state nor the private sector, moreover, was ideologically and fiscally competent to promote economic development as a priority policy" (Feuerwerker, 1980, p. 69).

As another sign of the slow response to the West, there were initiatives for teaching of foreign languages - in 1862 (Hao and Wang, 1980, 
p. 162), and for teaching of science and technology - in 1867, first classes of astronomy and mathematics, in 1879, physics, chemistry, physiology and international law (Hao and Wang, 1980, p. 162).

\subsection{Initial results of those two movements}

An evaluation of the nature of Chinese initial capitalist development has to integrate those consequences of the unintentional and intentional changes to the economy of the early nineteenth economy - a tributary mode of production or a peculiar combination between command, customary and market economies - that suffered that first clash with Western capitalism and began to change.

The initial results from the "first clash" and the combination between unintentional and intentional changes can be summarized by what the Chinese economy in 1880 was: basically a predominantly agricultural country. An estimate of size and overall economic structure is presented by Feuerwerker (1980, p. 2): from an "estimated gross national product of China", in 1880, agriculture represented 66.76 per cent and non-agricultural activities 33,23 percent. Within non-agricultural activities, manufacturing was 3.77 percent, mining 1.43 percent, trade 6.59 percent, services 7.23 and government services 4.91 percent.

This clash produced what type of economy? What type of peripheric capitalism?

There was a strong and resilient traditional agricultural economy, with a strong a resilient market network connecting a hierarchy of market towns and regions to coastal regions, a market that connected also those three economies - customary, market and command economies, now with two initial poles of capitalist dynamics - the commercial networks of the treaty ports, a link connecting the Chinese economy to global economy, and the small nucleus of foreign and Chinese-owned industrial firms that were another connection between global and domestic markets. The underdevelopment of the network of transport and communication systems (Feuerwerker, 1980, p. 41, p. 45) limited the integration of markets and other sources of capitalist dynamics. This Chinese economy with its limited integration of a national market can be contrasted with the USA economy being integrated, especially after 1866, in a large national market built with 
the help of the revolution in transport and communication described by Chandler (1977) - this contrast has consequences as the data in Figure 1 show after 1850: growth of USA GDP against stagnation in China.

Those coastal nodes of capitalist initial developments, given their limited size, given the strong participation of foreign agents and given the political situation that might have blocked a more autonomous development of domestic capitalist forces, were not able to impose a specific modern capitalist dynamic. But those nodes began important transformations that affected the handicraft industries all over China, with dynamic adaptations to new imports and new demands. Those changes were combined with other dynamic forces, initiated by political decision within China, related to the self-strengthening movement. Nodes of initial local industrialization could be identified, but they were not big enough to impose a new economic dynamics to a large economy still very traditional, in the sense of the persistence of elements of customary, command and market economies of the early XIX ${ }^{\text {th }}$ century.

In sum: at the end of the XIX ${ }^{\text {th }}$ Century the Chinese economy began a transformation under the impact of the initial shocks from the Industrial Revolution, from the Western presence at coastal cities. Those impacts transformed the Chinese economy, combining nodes of capitalist development - foreign and domestic - with the traditional economy inherited from early XIX ${ }^{\text {th }}$ Century. Those transformations took place still under the same political arrangement - the Ching dynasty, a form of state that did not help to spread those nodes of capitalist development (see Perkins, 1967).

\section{China's trajectory after 1900 and falling behind until 1949}

The outcome of the first impact of the Industrial Revolution and the first clash with the West was the establishment of nodes of capitalist development, dispersed by the Treaty Ports, and the delayed and slow reaction to this first impact by the Chinese polity was the self-strengthening movement, with limited initiatives to absorb foreign technologies. Those combined forces were not strong enough to impose a new dynamics to the Chinese economy. As a result, military weakness and political fragmentation, in great part defined by military defeats, were dominant elements 
of the political scene. Probably there was a vicious cycle between limited economic growth, military weakness vis-à-vis foreign powers and political fragmentation that blocked a unification of national markets, which in turn limited the scope of economic growth, blocking an initial endogenous and self-organized development.

After the "first clash" there was inertia, and a slow and late response. Defeats led to foreign presence in a growing number of treaty ports. Economically, this presence led to initial movements changing the pre-clash Chinese economy. Those changes led to one of the driving forces of a new economic system - capitalist dynamics - through passive insertion in the global economy under the British leadership of a new international division of labor. Later, especially after 1861, China witnessed an attempt to start a more active insertion in the global economy, as a result of movements such as "self-strengthening". This combination of strong passive insertion with late and weak active insertion in the global order led to a very peculiar variety of peripheric capitalism, with a low growth trajectory that was unable to create enough military strength to face new military challenges.

The last decade of the XIX ${ }^{\text {th }}$ Century puts forward a new challenge to China and a new military defeat, now to Japan in 1894-5. The defeat in the Sino-Japanese war (1894-1895) "revealed the failure of a policy proclaimed to be defense against foreign powers" (Kuo and Liu, 1978, p. 491). This defeat might represent a compounded impact of Industrial Revolution, as it showed the military effects of different speeds of response to the Industrial Revolution - Japan had initiated a successful catch up phase (Odagiri and Goto, 1993). The implications of those uneven speeds of absorption of Western technologies between Japan and China had other implications for China, beyond her new military defeat.

This defeat in the Sino-Japanese War had an important historical significance: a clear contrast between the responses from China and Japan to the Industrial Revolution - or as Ma (2008, p. 371) evaluates, "two modernization programs were put to test". On the one hand, China with the "selfstrengthening" movement had a late and incomplete start to acknowledge the meaning of new Western technologies, preserving the political institutions that were responsible for this late start - the Ching Empire. On the other hand, Japan, between 1868 and 1873, had managed a top to bottom political revolution (Skocpol, 1984, pp. 167-174) that reorganized the whole political and economic system. The results of this political revolution were 
a set of industrial policies to absorb Western technologies, a successful catch up process, that led to military power and expansionist policies.

This defeat had implications related to China's further fragmentation, but at the same time triggered a new process of internal mobilization looking for alternatives. This defeat opened a new process of reflection within China, as Spence (1995, p. 229) describes the "reform movement of 1898". New lessons from that defeat, as there was now another nation that China could learn from: Japan and its industrialization process, the potential use of Japan as a new basis for learning Western technologies (Jansen, 1980, p. 349). ${ }^{5}$

Therefore, in the late 1890s the Chinese, now knowing better foreigners and foreign countries, had at their disposal examples from Meiji Japan, to George Washington in the USA, Napoleon in France and Peter the Great in Russia (Spence, 1995, p. 233). This new era in Chinese history, after 1898, had political and reform movements fermenting that would lead to the Republic in 1911. In short, in 1898 began a reform movement that would end the Ching dynasty and start other sorts of experiment in industrialization processes (after 1911, see Feuerwerker, 1983).

Those experiments with industrialization are related to those initial nodes of capitalist development. The literature shows how strong those nodes were. Chan (2015, Table 2.2, p. 33) reviews the literature on China between 1911 and 1938. His summary of "key statistics" shows a strong industrial growth - an average of 9.4\% annual rate between 1912-1936 - according to data from Chang (1969), "coastal regions growing much faster" according to Rawski (1989) and a "per-capita net-domestic-product

5 The different speeds in the processes of search and absorption of Western technology in Japan and China are exemplified by Chang: "This situation again differed markedly from late-nineteenth-century Japan. An American who went to teach at one typical secular school in Japan in 1870 was impressed by the prominent place accorded to Western learning and the school's sizeable collection of Western books. Yet had he visited a typical Chinese academy even twenty years later, he would have found scarcely any evidence of Western influence" (Chang, 1980, p. 276). The same applies to the reception of economic and social ideas. As already mentioned, the first Chinese translation of the Wealth of Nations was published in 1901-2 (circa twenty years after the first written mentions to Smith's book in China). On the other side, Smith's name was known in Japan even before the Meiji Restoration. In 1863, during the Tokugawa Shogunate government, Dutch merchants were allowed to trade with residents in Nagasaki and brought Dutch books. Stirner's translation of the Wealth of Nations into German was introduced in Japan in 1859. A copy of McCulloch's 1863 edition was acquired by a Japanese library before 1868. The first Japanese translation of Smith's magnum opus was published between 1883 and 1888. Contrary to the Chinese version, it was translated into everyday Japanese that was widely understood (Mizuta 2002; Shaowen, 2002). 
growth rate between 1914-1918 and 1931-1935" of one region - Lower Yangzi $-1.1 \%$, greater than the Chinese average - 0.53 - and comparable to the Japanese growth rate $-1.4-$, according to $\mathrm{Ma}$ (2008).

Supported by those data, Chan (2015, p.32) evaluates that until 1937 China had a "robust embryonic capitalist economy". The strength of that growth is also mentioned by Brandt et al. (2016, p. 7), that shows how in those places "prewar industrial growth outstripped that of Japan". This is a powerful industrial dynamic that was limited to localized clusters or regions - regional concentration is a feature of the Chinese economy in the first half of the $X^{\text {th }}$ Century (Brandt et al., 2016, p. 8). Although strong and important, that industrial growth could not have had a very broad impact because, as Brandt et al. (2016, p. 7) put forward, "rapid growth from a minuscule base could not transform China into an industrial nation". This assessment is in line with Feuerwerker, who evaluates that limited impact: "[a]lthough a small modern industrial and transport sector, which first appeared in the late nineteenth century, continued to grow at a comparatively rapid rate, its impact was minimal before 1949" (Feuerwerker, 1983, p. 28).

After 1931 there was a new military defeat - another expression of the relative strength of Japan vis-à-vis the Chinese limited industrialization process: the annexation of Manchuria to the Japanese Empire (Spence, 1990, p. 378), that resulted in even further fragmentation, further weakness in the process of national unification. This annexation resulted also in a new regional nucleus and a new pattern of industrialization - "Manchurian industrialization" (Naughton, 2007, p. 43-45). This new political and military situation in relation to patterns of industrialization is summarized by Naughton as representing two types of industrialization, since there was an older "Treaty Port industrialization" or "enclave industrialization" (p. 43, p. 44) and this new "Manchurian industrialization" (p. 45).

In 1937 the war with Japan begins, with a country divided into at least three different governments: Kuomintang, the areas under control of CCP and the areas invaded by the Japanese (Spence, 1990, p. 433). As is well known, the process of the Second World War in the Pacific (1937-1945) was followed by the civil war ended only in 1949, with the creation of the PRC - a national reunification under the CCP. ${ }^{6}$

6 The complex intertwinement between those limited new patterns of economic dynamics and the changing and adverse political conjunctures is described by the periodization sug- 
The overall result of the interplay between the limited industrialization and political fragmentation until 1949 is shown in Figure 2: a dynamic that was not even able to preserve the gap vis-à-vis the USA - a gap that increased during the first half of the $\mathrm{XX}^{\text {th }}$ Century - a falling-behind period. This gap in 1870 was 0.217 and after that there was a systematic falling behind: 0.159 in 1890, 0.104 in 1913, 0.092 in 1938 and finally the lowest point in 1950: 0.047 (see Figure 1 in the Editorial of this Special Issue).

This new structure of Chinese economy was able to generate only a stagnant or low-growth trajectory, between 1870 and 1950, as Figure 2 shows.

Figure 2 GDP per capita - China, India, UK and USA (selected years between 1870 and 1950)

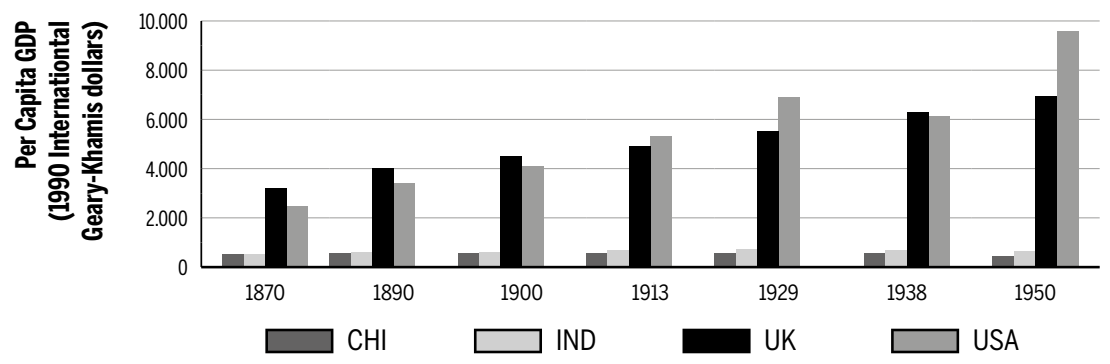

Source: Maddison (2010), authors' elaboration.

An explanation of the roots of this low growth trap, or of this fallingbehind period, may be related to this combination of localized capitalist development and political fragmentation in China. Those combined economic and political conditions contributed to limit the formation and unification of a modern national market, in contrast with the case of postbellum United States (Chandler, 1977). Feuerwerker in his overview of the 1912-1949 period highlights that "the organization of a unified market was never achieved" (1983, p. 28). The lack of this process of national market unification is behind the preservation of limited nodes of capitalist development in few regions and a pattern of very unequal development. Therefore, there was a falling-behind period between 1870 and 1949 . 
The fragmentation process of China in the conjuncture of the "first clash with the West" was to be solved only in 1949, as Fairbank (1987) describes the end of the civil war as "the reunification of China", a reunification led by Mao under a project of westernization of China (Schram 1991, p. 103). After that, a long and protracted catch up process was to take place (Naughton, 2007) until 1956 with the USSR as a benchmark - a middle-income country unable to finish its catch up process -, between 1956 and 1971 without a clear target, after 1971 the initial movements to have the leading capitalist country as the reference for her catch up process. Post-1949 policies, with turns, changes, trial and error, tragedies and transitions between different economic systems led to the breaking of that low growth trap and China reached the middle income level after more 60 years - in 2007 it overcame the level of $20 \%$ of USA per capita GDP (Maddison, 2010). But the evaluation of post-1949 policies falls outside the scope of this paper.

\section{References}

ALLEN, R. Lessons from history for the future of work. Nature, v. 550, pp. 321-324, 2017.

ANDERSON, P. Gandhi centre stage. London Review of Books, v. 34, n, 13, 5 July 2012. Available at: https://www.lrb.co.uk/the-paper/v34/n13/perry-anderson/gandhi-centre-stage. Accessed on 30 August 2014.

BANAJI, J. Theory as History: Essays on Modes of Production and Exploitation. Leiden: Brill, 2010.

BARROW, J. Travels in China: containing descriptions, observations and comparisons, made and collected in the course of a short residence at the imperial palace of Yuen-Min-Yuen, and on a subsequent journey through the country from Pekin to Canton. London: T. Cadell and W. Davies, 1804.

BASTIDE-BRUGUIERE, M. Currents of social change. In: In: FAIRBANK, J.; LIU, K-C. (ed.). The Cambridge History of China. Volume 11: Late Ching, 1810-1911, Part 2. Cambridge: Cambridge University Press, pp. 535-602, 1980.

BERGÈRE, M-C. The Chinese bourgeosie. In: FAIRBANK, J. The Cambridge History of China: Volume 12: Republican China 1912-1949, Part I. Cambridge: Cambridge University Press, pp. 712-825, 1983.

BOROKH, O. Adam Smith in Imperial China: Translation and Cultural Adaptation. OEconomia: History, Methodology, Philosophy, v. 2(4), pp. 411-441, 2012.

BRANDT, L.; MA, D.; RAWSKI, T. G. Industrialization in China, IZA Discussion Papers, No. 10096. Bonn: Institute for the Study of Labor (IZA), 2016. 
CHAN, K. S. The late Qing dinasty and the early Republic of China. IN: CHOW, G. C.; PERKINS, D. W. (eds) Routledge Handbook of the Chinese Economy. London/New York: Routledge, pp. 21-40, 2015.

CHANDLER JR., A. The Visible Hand - The Managerial Revolution in America Business. London: The Belknap Press of Harvard University Press, 1977.

CHANG, H. Intellectual change and the reform movement - 1890-8. In: FAIRBANK, J.; LIU, K-C. (ed). The Cambridge History of China. Volume 11: Late Ching, 1810-1911, Part 2. Cambridge: Cambridge University Press, pp. 274-338, 1980.

CHANG, J. K. Industrial development in pre-communist China: a quantitative analysis, Edinburgh: Edinburgh University Press, 1969.

CHEN, J.-G. The British view of Chinese civilization and the emergence of class consciousness. Eighteenth Century: Theory and Interpretation, v. 45 (2), pp. 193-205, 2004.

DARWIN, J. After Tamerlane: the rise and fall of Global Empires, 1400-2000. Cambridge: Cambridge University Press, 2007.

DARWIN, J. The Empire project: the rise and fall of the British World-System, 1830-1970. Cambridge: Cambridge University Press, 2009.

ELVIN, M. The pattern of Chinese past. Stanford: Stanford University Press, 1973.

ESCOSURA, L. P. The Economic Consequences of Independence in Latin America. In: BULMER-THOMAS, V.; COATSWORTH, J. H.; CONDE, R. C. The Cambridge Economic History of Latin America. Volume I: The Colonial Era and the Short Nineteenth Century. Cambridge: Cambridge University Press, pp. 463-504, 2006.

FAIRBANK, J. The creation of the treaty system. In: TWITCHETT, D.; FAIRBANK, J. (ed). The Cambridge History of China. Volume 10: Late Ching, 1810-1911, Part 2. Cambridge: Cambridge University Press, pp. 213-263, 1978.

FEUERWERKER, A. Economic trends in the late Ching Empire, 1870-1911. In: FAIRBANK, J.; LIU, K-C. (ed.). The Cambridge History of China. Volume 11: Late Ching, 1810-1911, Part 2. Cambridge: Cambridge University Press, pp. 1-69, 1980.

FEUERWERKER, A. Economic trends, 1912-1949. In: FAIRBANK, J. The Cambridge History of China. Volume 12: Republican China 1912-1949, Part I. Cambridge: Cambridge University Press, pp. 28-127, 1983.

FURTADO, C. Underdevelopment: to conform or to reform. In: MEIER, G. (ed) Pioneers of development. Second Series. Oxford: Oxford University/World Bank, pp. 203-227, 1987.

HAMILTON, A. Report on the subject of manufactures. In: The Works of Alexander Hamilton. Volume 1. New York: Williams and Whiting. pp. 157-276, 1810 [1791].

HANLEY, R. P. The "Wisdom of the State": Adam Smith on China and Tartary. American Political Science Review, v. 108(2), pp. 371-382, 2014.

HAO, Y.; WANG, E. Changing Chinese views of Western relations, 1840-1895. In: FAIRBANK, J.; LIU, K-C. (ed) The Cambridge History of China. Volume 11: Late Ching, 18101911, Part 2. Cambridge: Cambridge University Press, pp. 142-201, 1980.

HICKS, J. A theory of economic history. Oxford: Oxford University Press, 1969.

JANSEN, M. Japan and the Chinese Revolution of 1911. In: FAIRBANK, J.; LIU, K-C. (ed). 
The Cambridge History of China. Volume 11: Late Ching, 1810-1911, Part 2. Cambridge: Cambridge University Press, pp. 339-374, 1980.

JONES, S. M.; KUHN, P. A. Dynastic decline and roots of rebellion. In: TWITCHETT, D.; FAIRBANK, J. (ed). The Cambridge History of China. Volume 10: Late Ching, 1810-1911, Part 2. Cambridge: Cambridge University Press, pp. 107-162, 1978.

KUO, T-Y.; LIU, K-C. Self-strengthening: the pursuit of Western technology. In: TWITCHETT, D.; FAIRBANK, J. (ed). The Cambridge History of China. Volume 10: Late Ching, 18101911, Part 2. Cambridge: Cambridge University Press, pp. 491-542, 1978.

MA, D. Economic Growth in the Lower Yangzi Region of China in 1911-1937: A Quantitative and Historical Analysis. Journal of Economic History, v. 68, n. 2, pp. 355-392, 2008.

MADDISON, A. Historical statistics of the World Economy-1-2008 AD. Groningen Growth and Development Centre, 2010. Available at: http://www.ggdc.net/maddison/Historical_ Statistics/horizontal-file_02-2010.xls. Accessed on April 08, 2020.

METCALF, B.; METCALF, T. A concise history of modern India. Cambridge: Cambridge University Press, 2001.

MIZUTA, H. Translations of Adam Smith's works in Japan. In: TRIBE, K.; MIZUTA, H. (eds.). Critical bibliography of Adam Smith. London: Pickering \& Chatto, pp. 198-208, 2002.

MOKYR, J. The lever of riches: technological creativity and economic progress. Oxford: Oxford University Press, 1990.

MYERS, R., \& WANG, Y. Economic Developments, 1644-1800. In: PETERSON, W. (Ed.) The Cambridge History of China. Volume 9: Part One: The Ching Empire to 1800. Cambridge: Cambridge University Press, pp. 563-646, 2002.

NAUGHTON, B. The Chinese economy: transitions and growth. Cambridge/London: The MIT Press, 2007.

NEEDHAM, J. Science and civilization in China. Cambridge: Cambridge University Press, 1954.

ODAGIRI, H.; GOTO, A. The Japanese system of innovation: past, present and future. In: NELSON, R. (ed). National innovation systems: a comparative analysis. New York, Oxford: Oxford University, pp. 76-114, 1993.

PERKINS, D. H. Government as an obstacle to industrialization: the case of nineteenth-century China. Journal of Economic History, v. 27, n. 4, pp. 478-492, 1967.

POLANYI, K. The great transformation: the political origins of our time. Boston: Beacon Press, 2001 [1944].

POMERANZ, K. The great divergence: China, Europe and the making of modern world. Princeton: Princeton University Press, 2000.

RANKIN, M. B.; FAIRBANK. J. K.; FEUERWERKER, A. Introduction: perspectives on modern China's history. In: FAIRBANK, J. K.; FEUERWERKER, A. (eds). The Cambridge History of China, volume 13, Part 2. Cambridge: Cambridge University Press, pp. 1-73, 1986.

RAWSKI, T. G. Economic growth and employment in China. Oxford: Oxford University Press, 1979.

RAWSKI, T. G. Economic growth in prewar China. Berkeley: University of California Press, 1989.

REDMAN, D. A. The rise of political economy as a science. Cambridge: The MIT Press, 1997. 
SCHRAM, S. Mao Tse-Tung thought from 1949 to 1976. In: TWITCHETT, D.; FAIRBANK, J. (ed). The Cambridge History of China. Volume 15: The People's Republic, Part 2: Revolutions within the Chinese Revolution 1966-1982. Cambridge: Cambridge University Press, pp. 1-105, 1991.

SHAOWEN, Z. Adam Smith in China. In: TRIBE, K.; MIZUTA, H. (eds.). Critical bibliography of Adam Smith. London: Pickering \& Chatto, pp. 209-218, 2002.

SKOCPOL. T. Los estados y las revoluciones sociales. Mexico: Fondo de Cultura Económica, 1984 [1979].

SKINNER, G. W. Marketing and social structure in rural China - Part I. The Journal of Asian Studies, v. 24, n. 1, pp. 3-43, 1964.

SKINNER, G. W. Marketing and social structure in rural China - Part III. The Journal of Asian Studies, v. 24, n. 3, pp. 363-399, 1965.

SMITH, A. An inquiry into the nature and causes of the wealth of nations. Oxford: Oxford University Press, 1976 [1776].

SPENCE, J. D. Em busca da China moderna: quatro séculos de história. São Paulo: Companhia das Letras, 1995 [1990].

TENG, S.; FAIRBANK, J. China's response to the West - a documentary survey, 1839-1923, with a new preface. Cambridge: Harvard University Press, 1979.

WAKEMAN, F. The Canton trade and the Opium war. In: TWITCHETT, D.; FAIRBANK, J. (ed). The Cambridge History of China. Volume 10: Late Ching, 1810-1911, Part 2. Cambridge: Cambridge University Press, pp. 163-212, 1978.

\section{About the authors}

Hugo Eduardo da Gama Cerqueira - hugo@cedepar.ufmg.br

Centro de Desenvolvimento e Planejamento Regional, Universidade Federal de Minas Gerais, Belo Horizonte, MG, Brasil. ORCID: https://orcid.org/0000-0003-1036-0547.

Eduardo da Motta e Albuquerque-albuquer@cedeplar.ufmg.br

Centro de Desenvolvimento e Planejamento Regional, Universidade Federal de Minas Gerais, Belo Horizonte, MG, Brasil. ORCID: https://orcid.org/0000-0002-1591-875X.

We would like to thank the students that attended the disciplines ECN 010 TC3, in 2017, second semester (Revoluções tecnológicas e a dinâmica centro-periferia) and ECN 097 TD3, in 2018, second semester (Variedades de capitalismo na periferia). Financial support from CNPq (Grants 401054/2016-0 and 307787/2018-4) is acknowledged. We would like to thank the reports from two anonymous referees of Nova Economia - their comments and criticisms helped to better define the focus of this paper and their suggestions improved this version. The usual disclaimer applies.

\section{About the article}

Submission received on May 05, 2020. Approved for publication on February 27, 2021. 